\title{
To build a walled garden
}

\author{
Through cooperative ventures around the state, the UC Master Gardener program brings \\ horticultural knowledge to Californians in jails, detention centers and treatment facilities.
}

Youths at the Kings County Juvenile Center get down to work as part of a UC Master Gardener project. Research shows that gardening provides physical, emotional, social and economic benefits to those who participate in it.

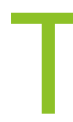

he UC Master Gardener Program delivers research-based information to the public, but not every member of the public is in public. Some reside temporarily in jails, detention centers or treatment facilities - so the UC Master Gardener Program meets them where they are.

In San Diego County, the UC Master Gardener Program conducts outreach at the County of San Diego Girls Rehabilitation Facility. In this collaboration with San Diego County's Probation Department and Office of Education, UC Master Gardener volunteers visit the facility twice a week to teach skills such as planting, irrigation and crop rotation. The young women eat the product of their labor - and also cultivate pollinating plants to attract monarch butterflies. Dayle Cheever, a UC Master Gardener volunteer, reports that staff at the facility have "truly embraced" the gardening initiative - and that many young women ask how to continue gardening, or pursue horticulture as a career, after they leave the facility.

In Sonoma County, through the Propagation for Education project, UC Master Gardener volunteers provide horticultural training to inmates at the North County Detention Facility. The project, a cooperative undertaking with the Sonoma County Sheriff's Office and Office of Education, focuses on propagation of plant materials such as shrubs, trees, perennials and ornamental plants. "My guys really soak it up," says Rick Stern, an adult corrections teacher with the county's Office of Education. Many inmates, after they leave the facility, retain an interest in gardening - they "always have a question" when Stern encounters them around town. And even if former inmates don't pursue horticulture as a career, they can share in the physical, emotional, social and economic benefits that, according to research, gardening confers on its practitioners (Benham 2014; Waitkus 2004).

A bit further south, UC Master Gardener volunteers collaborate with the Behavioral Health Division of Contra Costa Health Services to deliver gardening programs at four residential substance-abuse facilities - some of whose residents, having faced a choice between treatment and prison, chose treatment. UC Master Gardener volunteers such as Darlene DeRose visit the facilities several times a month, giving lessons on basic vegetable gardening topics such as soils, pollinators and pests. The lessons are followed by hands-on gardening work.

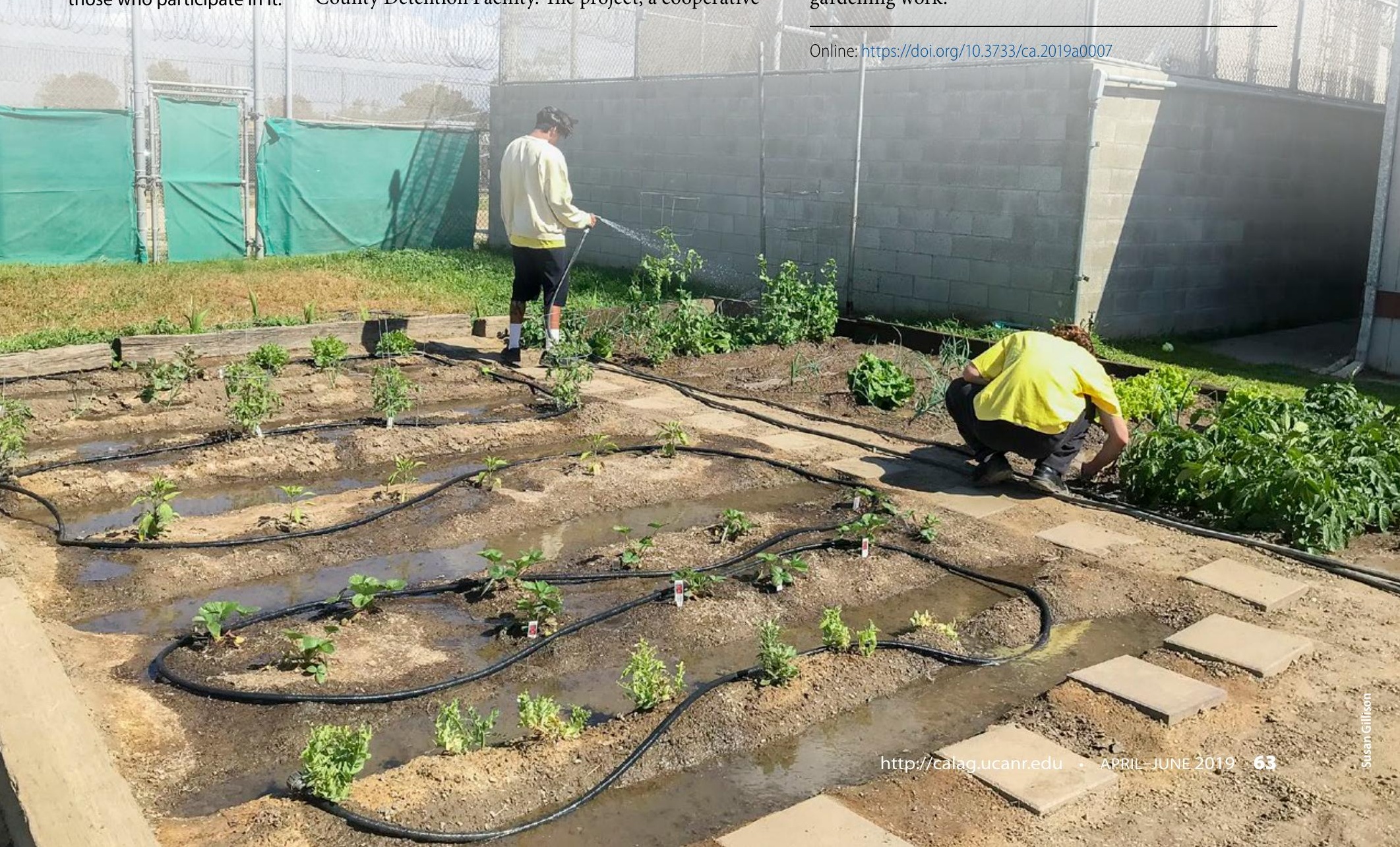




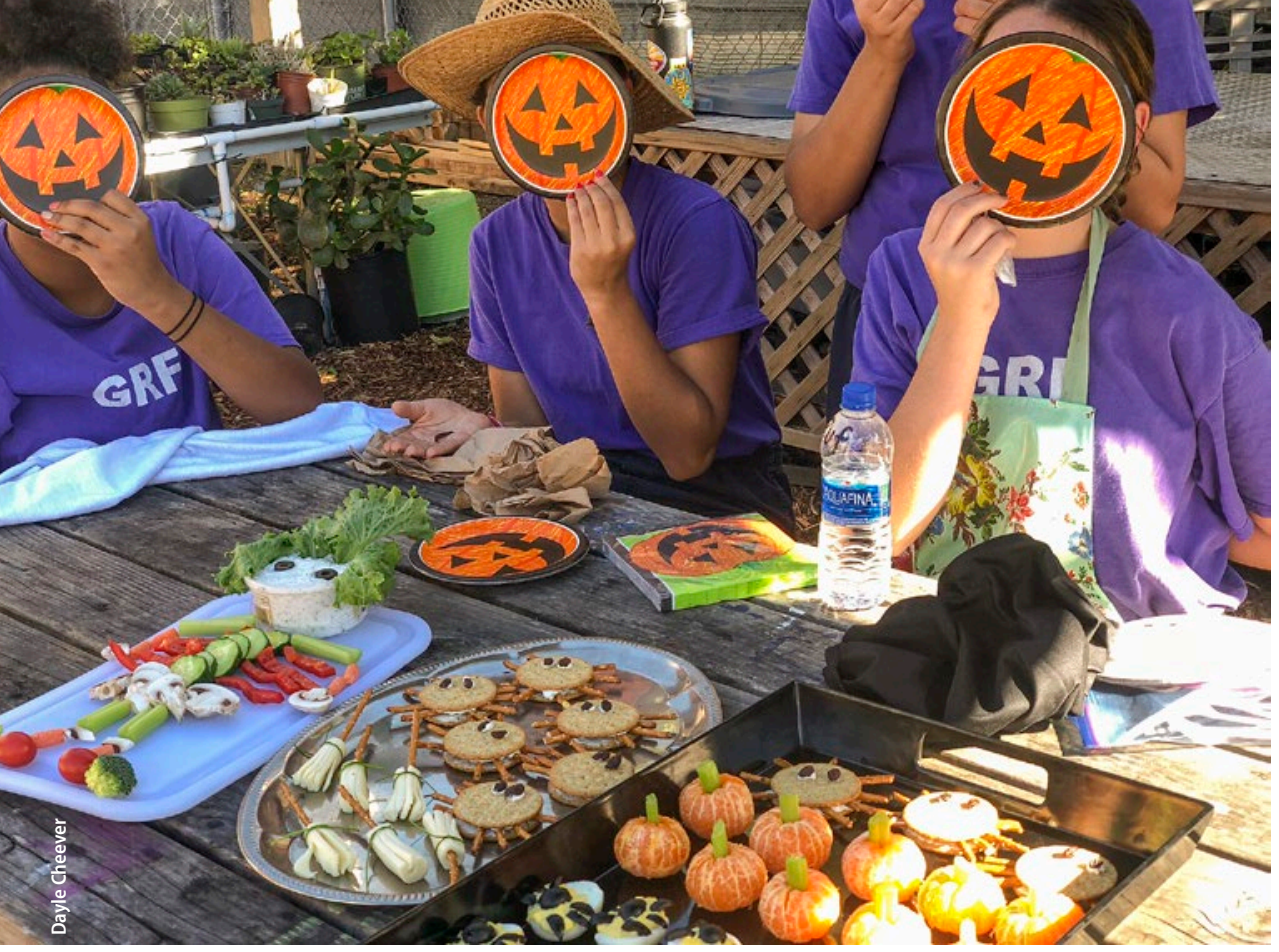

Young women at the County of San Diego Girls Rehabilitation Facility, participating in a UC Master Gardener project, get in the Halloween spirit.

A floral design adorns the ground at the County of San Diego Girls Rehabilitation Facility. Young women participating in the facility's UC Master Gardener project grow pollinating plants to attract monarch butterflies.

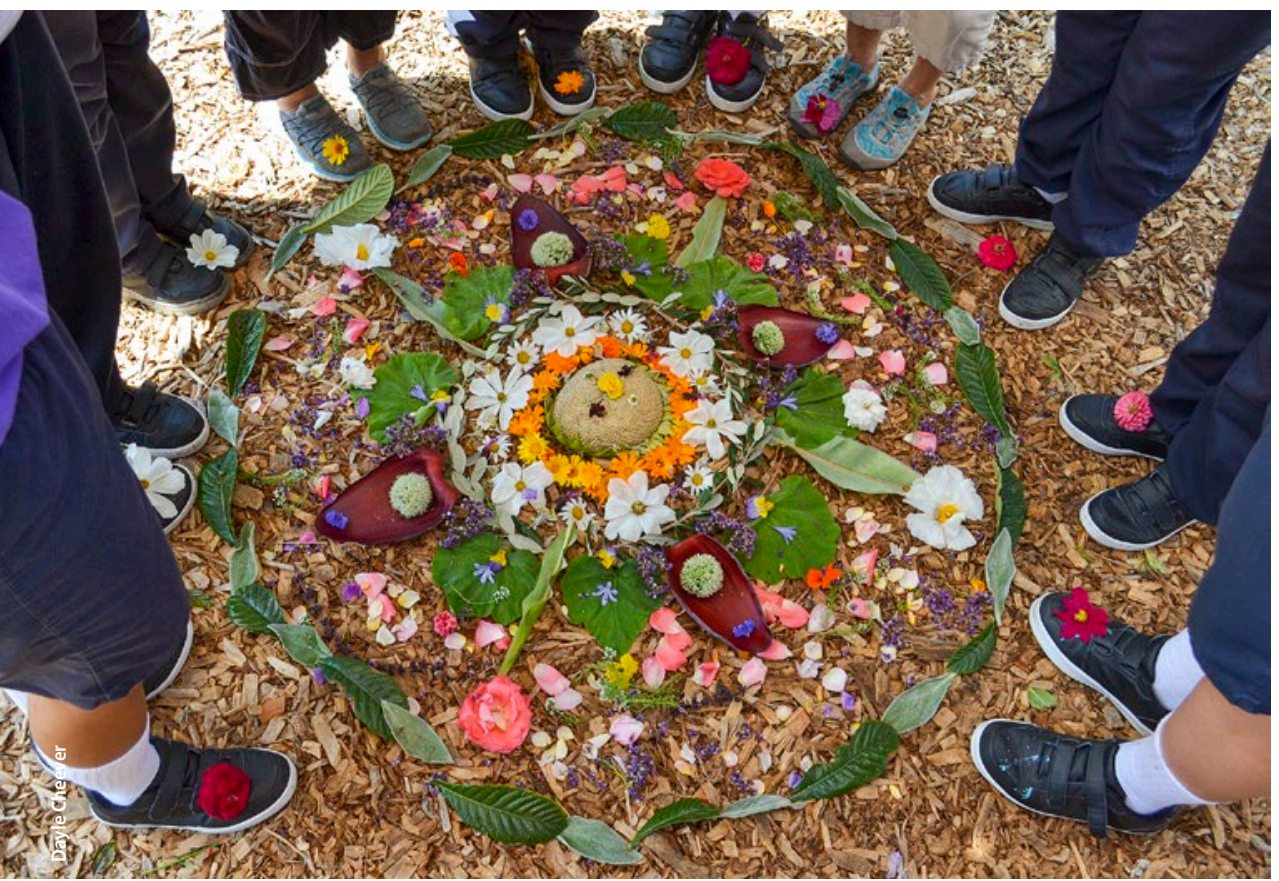

When UC Master Gardener volunteers began the project, DeRose says, "One facility had small raised beds, lying fallow, and the others had nothing." Today, the gardens yield plentiful fresh food that the residents harvest and make into meals. The participants are generally eager to learn, DeRose reports, though they

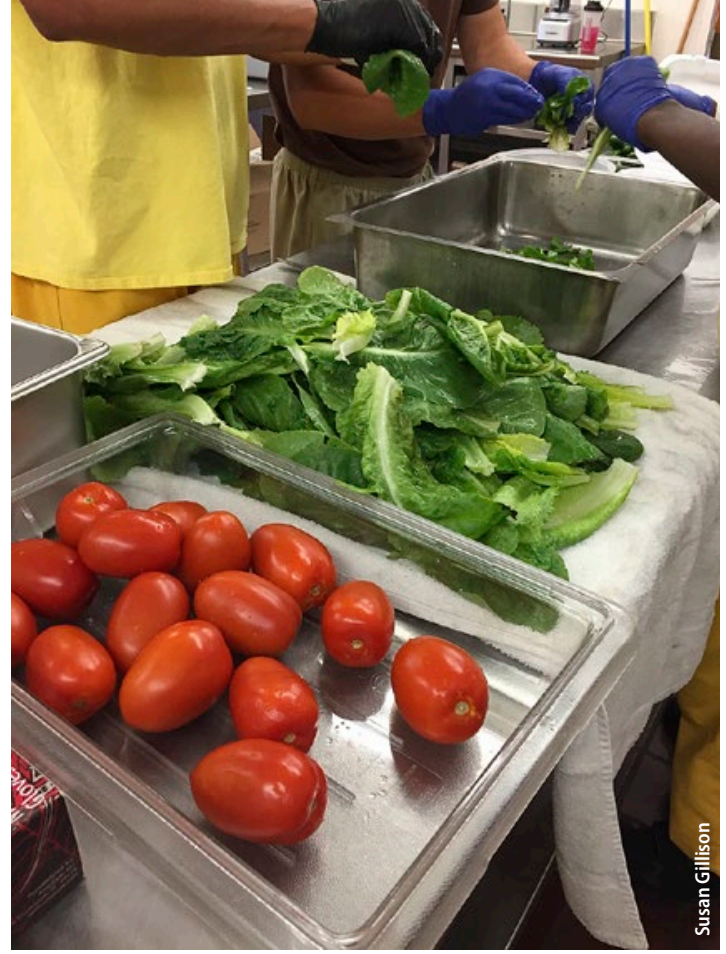

Incarcerated youth at the Kings County Juvenile Center prepare food grown on site.

educational and social services center for youth, on a project called the Leadership Garden. At Rancho Cielo, students aged 16 to 24 work toward high school diplomas as they develop marketable work skills. A majority of the students are on probation or parole - but others have had no dealings with the law, and all are free to come and go.

When UC Master Gardener volunteers such as Julie about basic things" - some students, for example, want to get rid of bees. The volunteers have learned lessons too, such as what to grow and not grow (lettuce is popular, eggplant anathema).

In Monterey County, the UC Master Gardener Program collaborates with Rancho Cielo, an Lorenzen visit, students from Rancho Cielo's culinary academy venture to the garden to work and learn. Most of the garden's harvest is sent to the academy's restaurant, where students prepare it for paying customers. When Lorenzen was interviewed for this article, the

restaurant was featuring Jerusalem artichokes from the Leadership Garden - and on the Monday preceding, the garden had yielded 28 pounds of leeks and 10 pounds each of lemons and mandarin oranges. That's a nice haul. But to Lorenzen, the garden is more than citrus fruit and aromatics. "Aside from raising my own children," she says, the Leadership Garden is "the most rewarding thing I've ever done." CA

- Lucien Crowder

\section{References}

Benham MK. 2014. From Utility to Significance: Exploring Ecological Connection, Ethics and Personal Transformation through a Gardening and Environmental Literacy Program within San Quentin State Prison. Master's thesis, San Jose State University, Department of Environmental Studies. https://scholarworks.sjsu. edu/etd_theses/4452

Waitkus KE. 2004. The Impact of a Garden Program on the Physical Environment and Social Climate of a Prison Yard at San Quentin State Prison. Master's thesis, Pepperdine University, School of Business and Management. https://pepperdine.contentdm.oclc org/digital/collection/p15093coll2/id/94 